\title{
KRITERIA KINERJA ENERGI UNTUK KENYAMANAN TERMAL PADA BANGUNAN FASILITAS PENDIDIKAN TINGGI DI INDONESIA Analisis dengan Metode Important Performance Analysis
}

\author{
Dian Ariestadi, Imam Alfianto, Mohammad Sulton \\ Jurusan Teknik Sipil Universitas Negeri Malang \\ Email: dianariestadi@gmail.com
}

\begin{abstract}
ABSTRAK
Gedung di negara beriklim tropis termasuk Indonesia paling banyak menggunakan energi untuk sistem tata udara $45-70 \%$, sistem tata cahaya $10-$ 20\%. SNI 03-6196-2000 tentang prosedur audit energi pada bangunan gedung, memiliki ruang lingkup meliputi perkantoran, hotel, pertokoan/pusat belanja, rumah sakit, apartemen dan rumah tinggal. Bangunan fasilitas pendidikan tinggi belum mendapat perhatian terkait dengan kinerja energi karena kenyamanan suhu dan pencahayaan. Tujuan penelitian adalah mengidentifikasi kriteria dasar sebagai indikator awal untuk melakukan penilaian (assesment) terhadap kinerja energi bangunan. Analisis dan identifikasi kriteria dilakukan dengan menggunakan metode Important Performance Analysis (IPA). Hasil penelitian menunjukkan bahwa dari sekitar 40 kinerja kriteria desain bangunan yang memiliki pengaruh dengan kenyamanan termal terdapat 24 faktor yang dipersepsikan penting oleh pengguna bangunan fasilitas bangunan pendidikan tinggi, meliputi kategori: (1) lokasi bangunan, (2) upaya reduksi panas sekitar bangunan, (3) denah bangunan, (4) bentuk arsitektur, (5) desain struktural dan selubung bangunan, (6) desain struktural dan selubung, (7) interior ruang, serta (8) sistem penghawaan dan pencahayaan buatan
\end{abstract}

Kata kunci: kinerja termal bangunan, bangunan fasilitas pendidikan tinggi, metode Important Performance Analysis

\section{Pendahuluan}

Perancangan bangunan mempunyai tujuan utama untuk meningkatkan kualitas hidup manusia. Keberadaan bangunan di dalam konteks lingkungan tidak terlepas dari berbagai pertimbangan dan batasan. Sepanjang sejarah, perkembangan arsitektur bangunan selalu terkait faktor iklim, energi, ketersediaan sumber daya dan upaya untuk menjamin sumber daya tersebut dapat terjamin secara berkelanjutan. Saat ini, pertimbangan penggunaan energi dalam bangunan sudah menjadi suatu kriteria yang diwajibkan di hampir semua negara di dunia.

Selama ini industri konstruksi adalah sektor industri yang paling akhir dipikirkan dapat membebani lingkungan. Namun pada kenyataannya industri konstruksi merupakan industri yang paling banyak ada dan tidak dapat dihindari akan terus berkembang setiap saat seiiring dengan pertumbuhan pendapatan per kapita negara. Menurut Agenda 21 on Sustainable Construction (CIB \& UNEP-IETC, 2002), industri konstruksi memberi beban yang besar terhadap lingkungan mulai dari fase perencanaan (pre-building phase), fase konstruksi/operasional (building phase) sampai fase demolisi (post-building phase). Pada semua fase tersebut perlu ditekankan perwujudan parameter keberlanjutan/sustainabilitas. 
Industri konstruksi di Indonesia, khususnya untuk konstruksi bangunan gedung secara teknis belum mempunyai perangkat untuk melakukan analisa, batasan/kontrol dan evaluasi terhadap dampaknya terhadap lingkungan, khususnya pada tahap prakonstruksi. Pembangunan konstruksi bangunan gedung saat ini diatur dalam UU No. 28 Tahun 2002 tentang Bangunan Gedung. Dalam undang-undang ini pertimbangan terhadap dampak lingkungan hanya dilakukan untuk bangunan tertentu yang dinilai akan banyak memberi beban pada lingkungan, padahal pada kenyataannya semua konstruksi memberi beban besar kepada lingkungan.

Seiring dengan pertumbuhan ekonomi yang pesat serta bertumbuhnya gedunggedung di Indonesia, penerapan efisiensi energi di gedung-gedung sesuai dengan Standar Nasional Indonesia menjadi hal yang sangat penting. Pada umumnya, gedung di negara beriklim tropis termasuk Indonesia paling banyak menggunakan energi untuk sistem tata udara (45-70\%), sistem tata cahaya (10-20\%), lift dan eskalator (2-7\%), serta alat-alat elektronik (2-10\%). Priatman (2003) menemukan bahwa penggunaan energi untuk kenyamanan termal berkisar 50\%-60\%, sedangkan untuk kenyamanan visual berkisar 30\%, atau dapat disimpulkan bahwa kualitas termal bangunan dan faktor cuaca menjadi faktor penentu yang dominan dalam penggunaan energi.

Memperhatikan kebijakan pemerintah tentang pendidikan, yaitu dalam UU No. 20 Tahun 2003 tentang Sistem Pendidikan Nasional terkait dengan sistem desentralisasi, menuntut pembangunan fisik yang cukup banyak, salah satunya adalah pada fasilitas pendidikan tinggi. Peraturan atau standar yang ada di Indonesia saat ini, yaitu SNI 03-6196-2000 tentang prosedur audit energi pada bangunan gedung, menyebutkan bahwa ruang lingkup standar ini hanya meliputi perkantoran, hotel, pertokoan/pusat belanja, rumah sakit, apartemen dan rumah tinggal. Selama ini, konstruksi bangunan di lingkungan fasilitas pendidikan tinggi belum mendapat perhatian yang layak terkait dengan kinerja energi dan keterkaitannya lingkungan global alami.

Sebagai dasar dari pengembangan standar desain maka perlu dilakukan kajian terhadap faktor-faktor desain bangunan, khususnya faktor-faktor desain yang berpengaruh terhadap kinerja termalnya. Penelitian ini bertujuan untuk melakukan evaluasi terhadap faktor-faktor desain yang berpengaruh kinerja termal bangunan fasilitas pendidikan tinggi Di Indonesia. Hasil yang diharapkan adalah peringkat kinerja faktor-faktor desain yang mempengaruhi kenyamanan termal bangunan untuk mendukung kenyamanan suhu dan kenyamanan pencahayaan. Hasil peneitian lebih lanjut dapat memberikan suatu rekomendasi, khususnya peran bangunan dalam memodifikasi iklim.

\section{Bahan dan Metode}

Analisis yang dilakukan akan memberikan deskripsi tentang kinerja faktorfaktor desain yang berkaitan dengan kenyamanan termal bangunan, yakni kenyamanan suhu dan kenyamanan pencahayaan. Identifikasi kriteria dilakukan dengan menggunakan metode Important Performance Analysis (IPA), yaitu suatu metode analisis yang merupakan kombinasi antara atribut-atribut tingkat kepentingan dan persepsi terhadap kualitas pelayanan ke dalam bentuk dua dimensi.

Langkah-langkah IPA adalah sebagai berikut:

(1) Mengidentifikasi elemen-elemen atau aspek-aspek kritis yang akan dievaluasi,

(2) Mengembangkan instrumen survei yang digunakan untuk mendapatkan penilaian tingkat kepentingan serta kinerja dari elemen-elemen atau aspek- 
aspek yang diperoleh di langkah pertama, salah satunya adalah dengan pembobotan,

(3) Menghitung nilai tingkat kesesuaian (Tki), dimana besarnya nilai Tki menggambarkan kepuasan responden, dan

(4) Menghitung nilai rata-rata tingkat kepentingan serta kinerja masing-masing elemen yang ditujukan untuk mengetahui posisi masing-masing atribut pada diagram kartesius, seperti pada gambar 1 berikut ini.

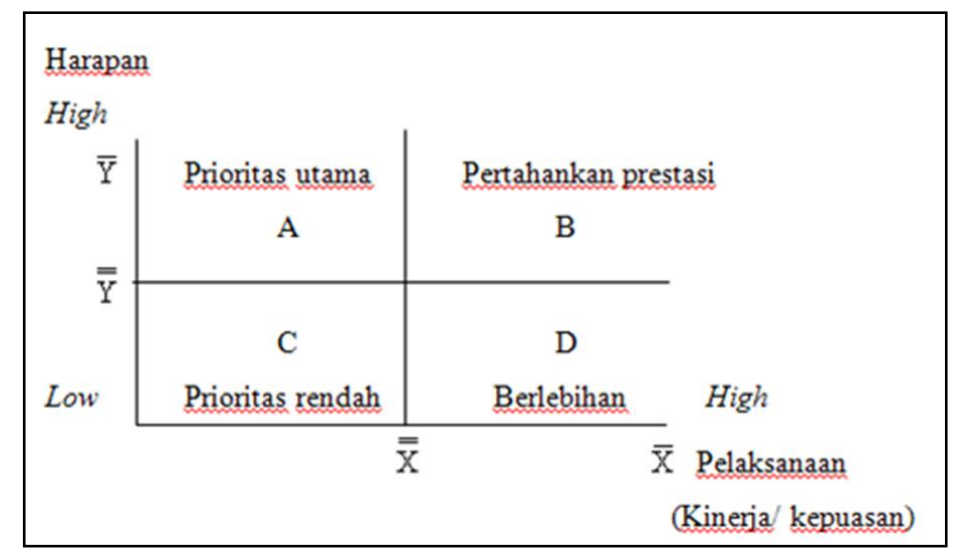

Gambar 1. Kuadran pada Diagram Kartesius IPA (Sumber: Supranto, 2001)

Penelitian akan dilakukan di 2 kategori wilayah yang berbeda, yaitu bangunan fasilitas pendidikan tinggi yang terletak di utara khatulistiwa (berada pada posisi garis Lintang Utara) dan di selatan khatulistiwa (posisi di garis Lintang Selatan). Hal ini berkaitan dengan diperlukannya data respon bangunan terhadap iklim regional, mengingat wilayah Indonesia meliputi daerah yang terletak di Lintang Utara sampai dengan Lintang Selatan.

Pengumpulan data dalam penelitian ini terdiri dari 2 tahap yaitu tahap untuk menentukan gedung di lingkungan fasilitas pendidikan tinggi serta tahap penentuan responden. Tahap penentuan gedung di lingkungan fasilitas pendidikan tinggi menggunakan metode purposive random sampling, untuk memberi gambaran tentang: a) tempat berlangsungnya kegiatan pembelajaran secara tatap muka baik dalam bentuk ceramah, diskusi, seminar, tutorial, dan sejenisnya; 2) tempat mahasiswa dan dosen memeroleh informasi dari berbagai media dan tempat pustakawan mengelola perpustakaan; 3) tempat penunjang kegiatan pembelajaran dan pencarian informasi yang menggunakan teknologi informasi dan komunikasi, serta mendukung kegiatan pembelajaran yang memanfaatkan komputer; 4) tempat aktivitas dosen; 4) tempat akademik khusus bidang ilmu, berupa Laboratorium penelitian dan/atau prasarana sejenis, seperti bengkel kerja, studio gambar dan studio perancangan, Laboratorium Micro Teaching, hingga ruang unit produksi; 5) tempat melakukan kegiatan pengelolaan manajemen dan administrasi perguruan tinggi, baik pada tingkat perguruan tinggi, fakultas maupun program studi; serta 6) sarana dan prasarana penunjang seperti beribadah, konseling, pelayanan kesehatan, gudang, kantin, fasilitas sanitasi, hingga area parkir.

Penentuan responden adalah keseluruhan gambaran sivitas akademika di lingkungan pendidikan tinggi pada gedung yang telah ditentukan, meliputi dosen, 
mahasiswa, serta staf pengelola atau karyawan. Untuk pengambilan sampel sivitas akademika yang sudah diketahui populasinya, dipergunakan rumus Slovin, dengan nilai batas ketelitian $90 \%$. Berdasarkan data rata-rata populasi gedung 600 orang maka responden setiap gedung sekitar 80 orang.

\section{Hasil dan Pembahasan}

Kemampuan bangunan dalam memberikan respon terhadap lingkungan termal terkait erat dengan performa elemen-elemen pembentuknya. Performa ini berupa desain bentuk, material, susunan ruang dan teknologi konstruksi, serta orientasinya. Menurut Evans (1980), keberhasilan bangunan dalam merespon lingkungan termal secara keseluruhan terkait dengan desain aspek-aspek pembentuk kinerja termal (thermal performance) bangunan, yaitu antara lain desain atap, plafond, lantai, serta building envelopes (dinding luar, jendela / bukaan pencahayaan, dan ventilasi / bukaan udara)

Metode analisis evaluatif kinerja faktor-faktor desain yang berkaitan dengan kenyamanan termal bangunan yakni kenyamanan suhu dan kenyamanan pencahayaan. Faktor-faktor tersebut menjadi atribut IPA yang akan dinilai tingkat kepuasan terhadap pelayanan dan tingkat kepentingannya. Pengembangan atribut berdasarkan: Pertama, faktor-faktor yang ditentukan dalam 7 variabel dalam The LEED 2009 for Existing Buildings: Operations \& Maintenance Rating System, yaitu: (1) Sustainable Sites, (2) Water efficiency, (3) Energy and Atmosphere, (4) Materials and Resources, (5) Indoor Environmental Quality, (6) Innovation in Operations, dan (7) Regional Priority. Kedua, parameter yang ditetapkan oleh Greenship Rating Tools untuk Gedung Terbangun, yaitu: (1) Manajemen tapak, (2) Efisiensi dan konservasi energi, (3) Pengelolaan penggunaan air, (3) Penghematan penggunaan material dan sumber daya alam, (4) Kualitas dan kenyamanan ruang dalam, dan (5) Manajemen pengelolaan bangunan. Ketiga: parameter yang terdapat dalam Buku Pedoman Energi Efisiensi untuk Desain Bangunan Gedung di Indonesia - Energy Efficiency and Conservation Clearing House Indonesia (EECCHI), yang meliputi: (1) Perencanaan dan lansekap, (2) Desain struktural dan selubung, (3) Desain pencahayaan dan listrik, (4) Desain HVAC, serta (5) Operasi dan Pemeliharaan bangunan.

Berdasarkan tinjauan tipologi perkembangan bangunan kampus, tujuan pengambilan lokasi: (1) Malang (lokasi peneliti): Gedung Fakultas Hukum di Kampus UB sebagai gambaran lingkungan kampus dengan pengembangan fisik gedung bertingkat tinggi/vertikal dan tipologi bangunan gedung perkuliahan sebagian besar kampus di Indonesia, (2) Surabaya: Lingkungan Fakultas Teknik Sipil dan Perencanaan Kampus ITS untuk gambaran keragaman kondisi geografis (pantai/panas), tipologi bangunan bertingkat rendah dengan denah memanjang, (3) Banda Aceh (utara): Gedung Perkuliahan Fakultas Ekonomu Kampus Unsyiah, sebagai gambaran tipologi bangunan bertingkat rendah dengan denah memanjang, dan (4) Manado (utara): Gedung Fakultas Pasca Sarjana Unsrat yang merupakan tipologi gedung bertingkat tinggi/vertikal

Hasil analisis IPA pada 4 (empat) lokasi tersebut dikelompokan pada dua wilayah yang terletak di utara khatulistiwa (berada pada posisi garis Lintang Utara) dan di selatan khatulistiwa (posisi di garis Lintang Selatan). Hal ini berkaitan dengan diperlukannya data respon bangunan terhadap iklim regional. Hasil analisis IPA pada diagram kartesian IPA seperti pada Gambar 2 dan Gambar 3.

Hasil perhitungan terhadap tingkat kesesuaian antara persepsi (X) dan kepentingan (Y) pengguna gedung terhadap masing-masing atribut pada kondisi 
gedung fasilitas kegiatan pendidikan perguruan tinggi diketahui nilai batas objektif persepsi dan nilai batas objektif tingkat kepentingan responden terhadap tribut-atribut penilaian kinerja termal pada bangunan fasilitas pendidikan tinggi. Nilai kesesuaian masing-masing atribut yang melebihi nilai kesesuaian rata-rata seluruh atribut, maka responden menilai atribut itu dalam kinerja yang sangat memuaskan. Sedangkan jika di bawah nilai kesesuaian rata-rata seluruh atribut, menandakan bahwa atribut tersebut dianggap perlu ditingkatkan kualitasnya. Hasil analisisnya meliputi empat saran berbeda berdasarkan ukuran tingkat kepentingan (importance) dan kualitas pelayanan (performance).

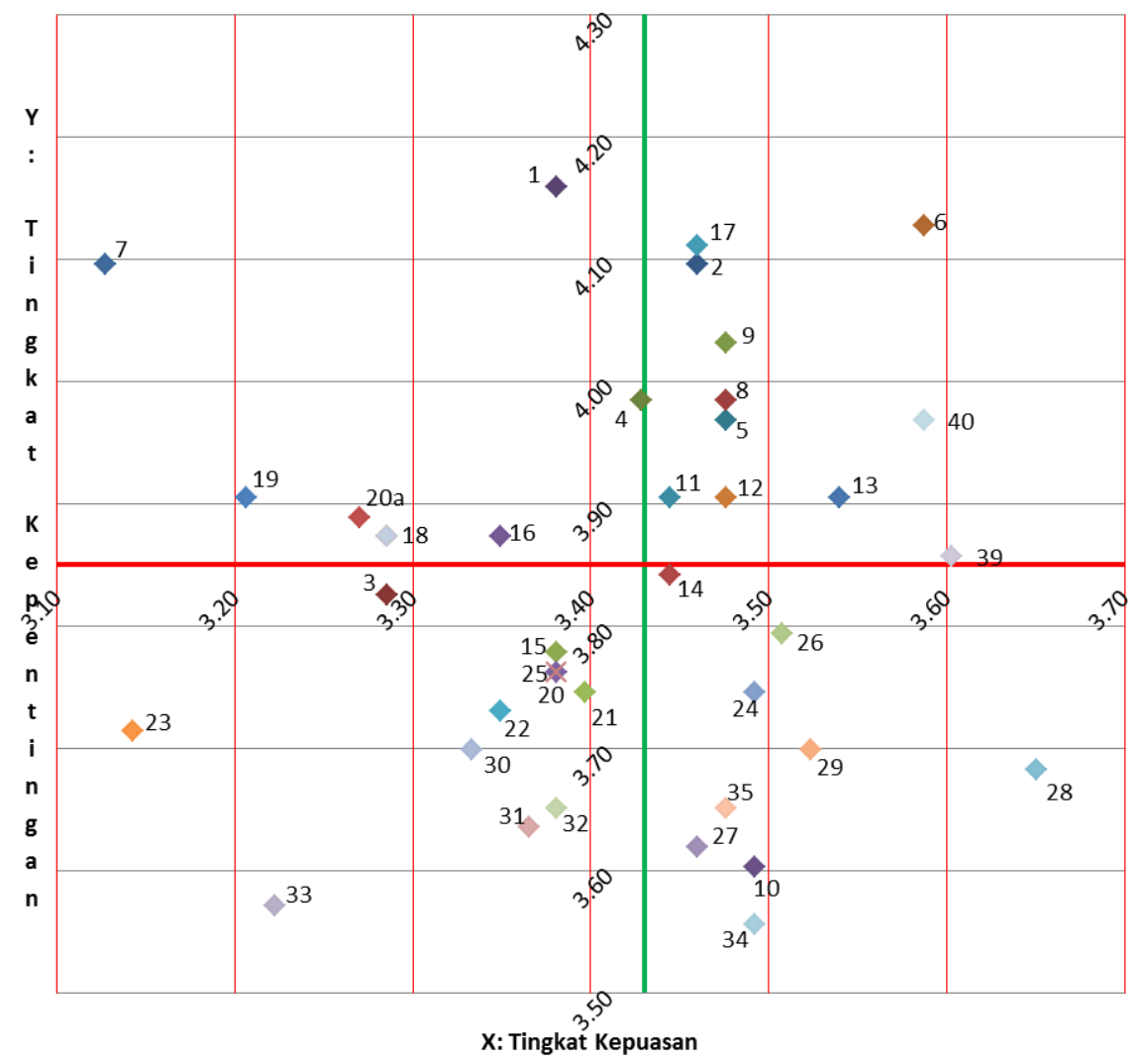

Gambar 2. Atribut pada Diagram Kartesius IPA untuk Wilayah Selatan 


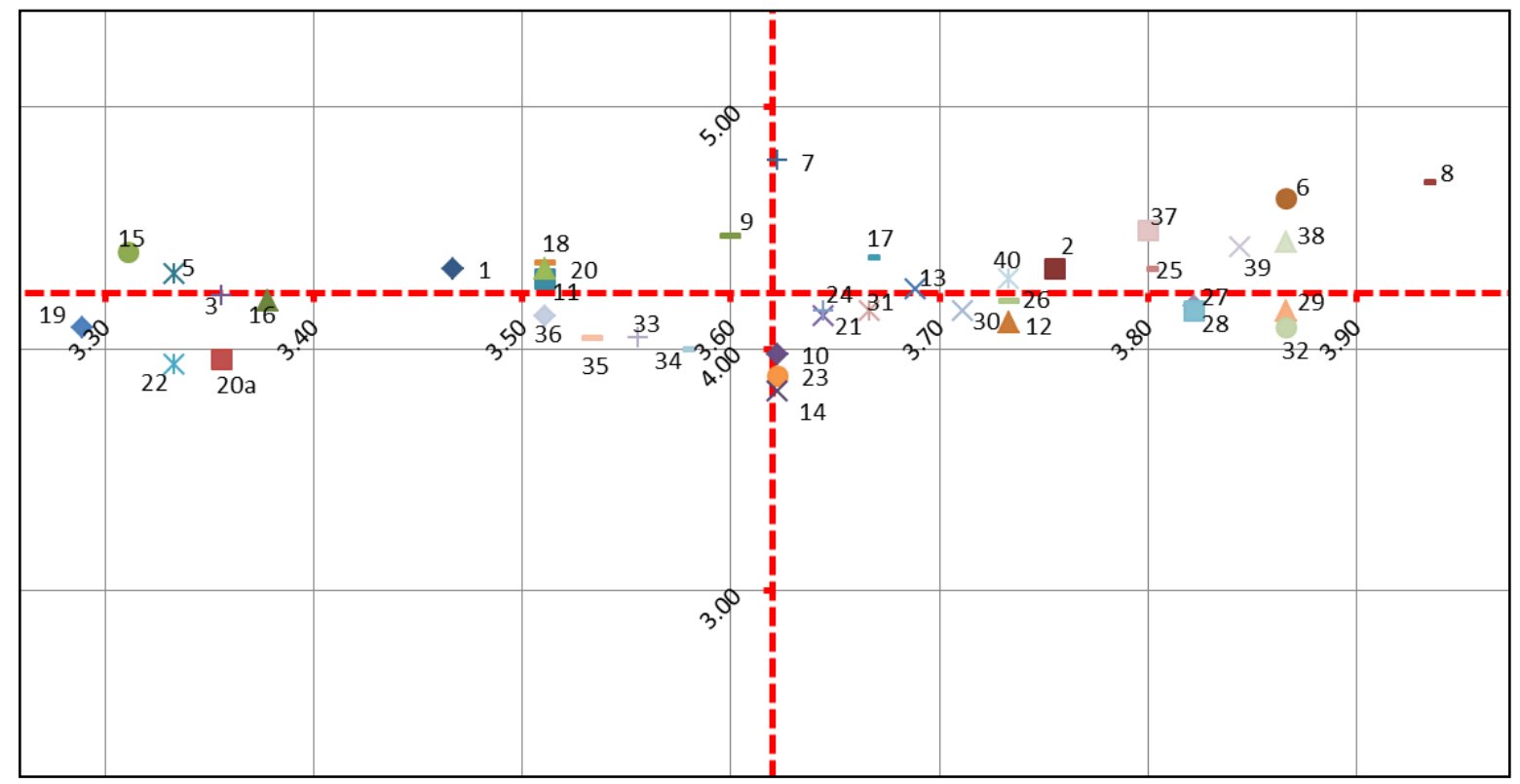

Gambar 3. Atribut pada Diagram Kartesius IPA untuk Wilayah Utara

Berdasarkan analisis tersebut terdapat beberapa atribut yang mempunyai tingkat persepsi tidak terlalu penting, yaitu atribut yang mendapatkan rangking III dan IV. Atribut dengan angka rangking III dengan prioritas rendah (Low Priority) adalah atribut-atribut yang mempunyai tingkat persepsi atau kinerja aktual yang rendah sekaligus dianggap tidak terlalu penting dan atau terlalu diharapkan oleh pengguna bangunan, sehingga tidak perlu memprioritaskan atau terlalu memberikan perhatian pada faktor-faktor tersebut. Atribut dengan angka rangking IV adalah atribut yang dianggap terlalu berlebih (Possibly Overkill). Atribut-atribut tersebut dianggap tidak terlalu penting dan atau tidak terlalu diharapkan. Hasil pemeringkatan atribut-atribut tersebut seperti pada Tabel 2.

Tabel 1. Rekapitulasi Atribut IPA dengan Kategori Persepsi Penting

\begin{tabular}{llcc}
\hline \multirow{2}{*}{ No } & Atribut IPA & Rangking & Rangking \\
\cline { 3 - 4 } & Lokasi bangunan yang mempengaruhi & Selatan & Utara \\
\hline & kenyamanan suhu dan pencahayaan & & \\
\hline 1 & Kondisi cuaca pada lokasi bangunan & I & I \\
2 & Arah hadap (orientasi) bangunan & II & II \\
\hline \multirow{3}{*}{ Upaya reduksi panas sekitar bangunan } & I & I \\
4 & $\begin{array}{l}\text { Penggunaan vegetasi (softscape) yang bebas dari } \\
\text { bangunan taman (hardscape) }\end{array}$ & II & I \\
& $\begin{array}{l}\text { Penggunaan material atap bangunan di sekitar } \\
\text { gedung yang tidak memantulkan panas (Heat } \\
\text { Island Effect) }\end{array}$ & & \\
\hline & $\begin{array}{l}\text { Denah bangunan (tata letak ruang) yang } \\
\text { berpengaruh pada kenyamanan suhu dan } \\
\text { pencahayaan }\end{array}$ & & \\
\hline 5 & $\begin{array}{l}\text { Letak ruangan mendukung kenyamanan suhu } \\
\text { dalam ruang }\end{array}$ & II & II
\end{tabular}




\begin{tabular}{|c|c|c|c|}
\hline 6 & $\begin{array}{l}\text { Letak ruangan memberikan penerangan alami yang } \\
\text { nyaman }\end{array}$ & $\mathrm{I}$ & II \\
\hline 7 & $\begin{array}{l}\text { Luasan ruang mendukung kenyamanan suhu dalam } \\
\text { ruang }\end{array}$ & II & II \\
\hline \multirow[t]{2}{*}{8} & $\begin{array}{l}\text { Luasan ruang memberikan penerangan alami yang } \\
\text { nyaman }\end{array}$ & II & I \\
\hline & $\begin{array}{l}\text { Bentuk bangunan (Arsitektur) yang } \\
\text { berpengaruh pada kenyamanan suhu dan } \\
\text { pencahayaan }\end{array}$ & & \\
\hline 9 & Material atap mereduksi panas & II & I \\
\hline 10 & Bentuk/konstruksi dinding luar bangunan & II & IV \\
\hline 11 & $\begin{array}{l}\text { Jenis material dinding luar bangunan yang } \\
\text { digunakan }\end{array}$ & II & II \\
\hline 12 & Bentuk elemen penghalang panas & III & I \\
\hline \multirow[t]{2}{*}{13} & Bentuk elemen penghalang silau cahaya & I & III \\
\hline & $\begin{array}{l}\text { Desain struktural dan selubung bangunan yang } \\
\text { mempengaruhi kenyamanan suhu }\end{array}$ & & \\
\hline 14 & $\begin{array}{l}\text { Luas bukaan jendela/pintu atau bukaan udara lain } \\
\text { di dinding untuk mendapatkan udara alami } \\
\text { (ventilasi) }\end{array}$ & II & II \\
\hline 15 & $\begin{array}{l}\text { Bentuk atau sistem konstruksi bukaan } \\
\text { jendela/pintu atau bukaan udara lain di dinding } \\
\text { untuk mendapatkan udara alami (ventilasi) }\end{array}$ & I & I \\
\hline 16 & $\begin{array}{l}\text { Luas bukaan di atap atau langit-langit untuk } \\
\text { mendapatkan udara alami (ventilasi) }\end{array}$ & $\mathrm{I}$ & III \\
\hline \multirow[t]{2}{*}{17} & $\begin{array}{l}\text { Bentuk atau sistem konstruksi bukaan di atap atau } \\
\text { langit-langit untuk mendapatkan udara alami } \\
\text { (ventilasi) }\end{array}$ & $\mathrm{I}$ & III \\
\hline & $\begin{array}{l}\text { Desain struktural dan selubung bangunan yang } \\
\text { mempengaruhi kenyamanan pencahayaan }\end{array}$ & & \\
\hline \multirow[t]{2}{*}{18} & $\begin{array}{l}\text { Luas bukaan di dinding (jendela/pintu, bouvenlicht, } \\
\text { atau lobang cahaya lain) untuk mendapatkan } \\
\text { terpaan sinar matahari (fenetrasi dinding) }\end{array}$ & III & I \\
\hline & $\begin{array}{l}\text { Interior Ruang yang berpengaruh pada } \\
\text { kenyamanan suhu dan pencahayaan }\end{array}$ & & \\
\hline 19 & $\begin{array}{l}\text { Jenis material dinding di dalam ruang yang } \\
\text { digunakan }\end{array}$ & III & II \\
\hline \multirow[t]{2}{*}{20} & $\begin{array}{l}\text { Penggunaan elemen interior penghalang } \\
\text { panas/cahaya dari luar (tirai, blind, dll) }\end{array}$ & I & III \\
\hline & Sistem penghawaan dan pencahayaan buatan & & \\
\hline 21 & $\begin{array}{l}\text { Sistem penghawaan buatan untuk pendinginan } \\
\text { ruang yang nyaman }\end{array}$ & II & II \\
\hline 22 & $\begin{array}{l}\text { Sistem penghawaan buatan untuk pendinginan } \\
\text { ruang (AC, kipas angin, dll) yang terintegrasi } \\
\text { dengan ventilasi alami }\end{array}$ & II & II \\
\hline 23 & $\begin{array}{l}\text { Sistem pencahayaan listrik tidak membuat } \\
\text { peningkatan panas internal }\end{array}$ & II & II \\
\hline 24 & $\begin{array}{l}\text { Pencahayaan listrik diintegrasikan dengan sinar } \\
\text { matahari }\end{array}$ & II & II \\
\hline
\end{tabular}


Berdasarkan hasil analisis maka dari sekitar 40 kinerja faktor-faktor desain bangunan fasilitas pendidikan tinggi di Indonesia yang memiliki pengaruh terhadap kenyamanan termal terdapat 24 faktor yang dipersepsikan penting oleh pengguna bangunan karena berada pada kuadran I dan IV atau dengan rangking I dan II. Faktorfaktor tersebut dikelompokkan dalam 8 kategori utama.

\subsection{Lokasi Bangunan yang Mempengaruhi Kenyamanan Suhu dan Pencahayaan}

Kondisi cuaca pada lokasi bangunan merupakan faktor desain yang dipersepsikan penting tetapi memiliki kinerja yang tidak memuaskan sehingga harus mendapatkan perhatian penting dalam desain. Dalam kriteria Greenship yang dikembangkan Di Indonesia (GBCI, 2012), tolok ukur dari kriteria ini meliputi: menghindari pembangunan di area greenfields dan menghindari pembukaan lahan baru, memilih daerah pembangunan dengan ketentuan $\mathrm{KLB}>3$, melakukan revitalisasi dan pembangunan di atas lahan yang bernilai negatif dan tak terpakai karena bekas pembangunan atau dampak negatif pembangunan, menggunakan berbagai material untuk menghindari efek heat island pada area perkerasan non-atap sehingga nilai albedo (daya refleksi panas matahari) minimum 0,3 sesuai dengan perhitungan, serta dapat melakukan pengurangan emisi CO2 dengan menggunakan grid emission factor yang telah ditetapkan dalam Keputusan DNA pada B/277/Dep.III/LH/01/2009.

Orientasi bangunan merupakan kriteria yang dipersepsikan penting tetapi telah memiliki kinerja yang memuaskan. Kriteria ini bertujuan untuk memahami orientasi dan tata letak bangunan untuk mendukung kenyamanan suhu dan kenyamanan pencahayaan pada bangunan. Tolok ukur yang hasrus dicapai adalah merencanakan arah hadap bidang vertikal bangunan dengan faktor radiasi matahari (SF, W/m2) yang terkecil, dihitung antara jam 07.00 sampai dengan jam 18.00 (SNI 03-6389-2000).

\subsection{Upaya Reduksi Panas Sekitar Bangunan}

Upaya reduksi panas melalui kriteria pengadaan vegetasi (softscape) yang bebas dari bangunan taman (hardscape) merupakan kriteria penting dan memiliki kinerja yang harus diperbaiki. Beberapa tolok ukur yang dapat dipertimbangkan adalah dengan mempertimbangkan Peraturan Menteri PU No. 5/PRT/M/2008 mengenai Ruang Terbuka Hijau (RTH) Pasal 2.3.1 tentang Kriteria Vegetasi untuk Pekarangan. Penggunaan tanaman yang telah dibudidayakan secara lokal, sebesar $60 \%$ luas tajuk pohon dewasa terhadap luas area lansekap, Desain lansekap berupa vegetasi (softscape) pada sirkulasi utama pejalan kaki menunjukkan adanya pelindung dari panas akibat radiasi matahari, serta terpaan angin kencang (GBCI, 2012).

Kriteria penggunaan material atap bangunan di sekitar gedung yang tidak memantulkan panas (Heat Island Effect) merupakan kriteria yang dianggap penting tetapi umumnya dalam kinerja memuaskan. Tolok ukurnya adalah menggunakan berbagai material untuk menghindari efek memantulkan panas pada area atap gedung sehingga nilai albedo (daya refleksi panas matahari) minimum 0,3 sesuai dengan perhitungan, serta upaya untuk menggunakan green roof sebesar $50 \%$ dari luas atap.

\subsection{Denah Bangunan yang Berpengaruh pada Kenyamanan Suhu dan Pencahayaan}

Kriteria pada kategori ini pada dasarnya meliputi letak dan luas ruangan baik untuk mendukung kenyamanan suhu ataupun untuk kenyamanan pencahayaan. Untuk mencapai kenyamanan suhu dan kelembaban udara ruangan yang dikondisikan stabil untuk meningkatkan produktivitas pengguna gedung perlu dipertimbangkan penggunaan ventilasi alami yang optimal untuk mengurangi konsumsi energi dan 
mendukung desain bangunan yang memungkinkan ventilasi alami semaksimal mungkin, serta penggunaan ventilasi yang efisien di area publik (non nett lettable area) untuk mengurangi konsumsi energi.

Untuk kenyamanan pencahayaan adalah dengan penggunaan pencahayaan alami yang optimal untuk mengurangi konsumsi energi dan mendukung desain bangunan yang memungkinkan pencahayaan alami semaksimal mungkin. Tolok ukur yang digunakan adalah penggunaaan cahaya alami secara optimal sehingga minimal 30\% luas lantai yang digunakan untuk bekerja mendapatkan intensitas cahaya alami minimal sebesar 300 lux, menggunakan cara perhitungan faktor langit dan faktor pencahayaan siang hari sesuai SNI 03-12396-1991, serta tingkat pencahayaan (iluminasi) di setiap ruang kerja sesuai dengan SNI 03-6197-2000 tentang Konservasi Energi pada Sistem Pencahayaan.

\subsection{Bentuk Arsitektur yang Berpengaruh pada Kenyamanan Suhu dan Pencahayaan}

Faktor bentuk arsitektur meliputi kriteria material dan konstruksi dinding dan atap, serta penghalang panas maupun silau. Kriteria penggunaan material dengan pertimbangan memasang material isolasi pada atap (modifikasi Uw dan Ur) - (SNI 036389-2000), dengan pertimbangan: nilai absorbtansi termal $(\alpha)$, nilai konduktivitas termal bahan, resistansi lapisan udara luar, resistansi termal bahan, resistansi termal rongga udara, dan resistansi lapisan udara permukaan. Sistem konstruksi dinding dan atap dapat mempertimbangkan peemasangan konstruksi isolasi pada dinding dan atap, pemasangan jendela dengan kaca ganda, atau konstruksi selubung bangunan yang memenuhi ketentuan sesuai SNI 03-6389-2000. Kriteria penghalang panas dan suhu dengan cara: memasang sarana peneduh pada jendela luar (SNI 03-6389-2000) berupa sirip horisontal, sirip vertikal dan pelindung matahari bentuk kotak segi empat, serta merancang bentuk elemen peneduh pada jendela luar agar pemanfaatan cahaya alami untuk masuknya radiasi matahari langsung ke dalam bangunan harus dibuat seminimal mungkin.

\subsection{Desain Struktural dan Selubung Bangunan untuk Kenyamanan Suhu}

Desain struktur dan selubung bangunan untuk kenyamanan suhu pada dasarnya berkaitan dengan sistem, dimensi dan material pada suatu desain ventilasi untuk menjaga dan meningkatkan kualitas udara di dalam ruangan dengan melakukan introduksi udara luar ruang sesuai dengan kebutuhan laju ventilasi untuk kesehatan pengguna gedung. Dalam GBCI (2012) disebutkan bahwa luas dan sistem konstruksi bukaan di dinding, atap atau langit-langit yang menunjukkan adanya potensi introduksi udara luar minimal sesuai dengan Standar ASHRAE 62.1-2007 atau Standar ASHRAE edisi terbaru. Ruangan dengan kepadatan tinggi, yaitu $<2.3 \mathrm{~m} 2$ per orang dilengkapi dengan instalasi sensor gas karbon dioksida (CO2) yang memiliki mekanisme untuk mengatur jumlah ventilasi udara luar sehingga konsentrasi C02, di dalam ruangan tidak lebih dari 1.000 ppm.

\subsection{Desain Struktural dan Selubung Bangunan untuk Kenyamanan Pencahayaan}

Desain struktur dan selubung bangunan untuk kenyamanan pencahayaan adalah untuk mendorong penggunaan pencahayaan alami yang optimal untuk mengurangi konsumsi energi dan mendukung desain bangunan yang memungkinkan pencahayaan alami semaksimal mungkin. Tolok ukur yang dapat digunakan adalah mendapatkan tingkat pencahayaan (iluminasi) di setiap ruang kerja sesuai dengan SNI 03-6197-2000 
tentang Konservasi Energi pada Sistem Pencahayaan, serta mengurangi angka perbandingan jendela luar dan dinding luar (modifikasi WWR) - (SNI 03-6389-2000)

\subsection{Interior Ruang yang Berpengaruh pada Kenyamanan Suhu dan Pencahayaan}

Kriteria yang paling dianggap penting adalah penggunaan jenis material untuk komponen interior yang dapat mereduksi panas, tidak menimbulkan panas pada lingkungannya. Material yang dipasang sesuai SNI 03-6389-2000, dengan pertimbangan: nilai absorbtansi termal $(\alpha)$, nilai konduktivitas termal bahan, resistansi lapisan udara luar, resistansi termal bahan, resistansi termal rongga udara, dan resistansi lapisan udara permukaan. Selain itu perlu dipertimbangkan penggunaan warna cat warna yang lebih terang untuk elemen interior.

\subsection{Sistem Penghawaan dan Pencahayaan Buatan}

Sistem tata udara yang dapat bekerja dengan hemat energi tanpa mengurangi persyaratan fungsinya. Tolok ukur yang digunakan antara lain: menetapkan perencanaan kondisi termal ruangan secara umum pada suhu $25 \mathrm{oC}$ dan kelembaban relatif $60 \%$, menggunakan peralatan AC dengan COP minimum 10\% lebih besar dari SNI 03-6390-2011 atau SNI edisi terbaru, tidak menggunakan chloro fluoro-carbon (CFC) sebagai refrigerant, serta Panduan pengoperasian dan pemeliharaan seluruh sistem AC (chiller, Air Handling Unit, cooling tower). Selain itu perlu juga dipertimbangkan untuk tidak mengkondisikan (tidak memberi AC) ruang WC, tangga, koridor, dan lobi lift, serta melengkapi ruangan tersebut dengan ventilasi alami ataupun mekanik.

Penggunaan energi untuk pencahayaan buatan yang sehemat mungkin dengan mengurangi daya terpasang. Tolok ukur yang digunakan adalah menggunakan lampu dengan iluminansi (tingkat pencahayaan) ruangan sesuai dengan SNI 03-6197-2011, melakukan penghematan dengan lampu yang memiliki daya untuk pencahayaan lebih hemat 20\% dari daya, pemilihan armatur yang mempunyai karakteristik distribusi pencahayaan sesuai dengan penggunaannya, mempunyai efisiensi yang tinggi dan tidak mengakibatkan silau atau refleksi yang mengganggu, serta menggunakan daya listrik maksimum per meter persegi tidak boleh melebihi nilai sebagaimana tercantum pada tabel 2 dalam SNI 03-6197-2011. Semua sistem pencahayaan bangunan gedung harus dapat dikendalikan secara manual atau otomatis, kecuali yang terhubung dengan sistem darurat.

\section{Kesimpulan}

Persepsi pengguna bangunan fasilitas pendidikan tinggi di Indonesia khususnya pada 4 kampus kajian di Malang, Surabaya, Manado dan Banda Aceh menunjukkan bahwa dari sekitar 40 kinerja faktor-faktor desain bangunan yang memiliki pengaruh dengan kenyamanan termal terdapat 24 faktor yang dipersepsikan penting oleh pengguna bangunan. Faktor-faktor tersebut berkaitan dengan:

(a) kondisi cuaca dan orientasi bangunan mendukung kenyamanan termal bangunan;

(b) reduksi panas melalui kriteria pengadaan vegetasi dan material atap bangunan dan lingkungan di sekitar gedung yang tidak memantulkan panas (Heat Island Effect);

(c) letak dan luas ruangan baik untuk mendukung kenyamanan suhu ataupun untuk kenyamanan pencahayaan; 
(d) kriteria material dan konstruksi dinding dan atap, serta penghalang panas maupun silau;

(e) sistem, dimensi dan material pada suatu desain ventilasi untuk menjaga dan meningkatkan kualitas udara di dalam ruangan dengan melakukan introduksi udara luar ruang sesuai dengan kebutuhan laju ventilasi untuk kesehatan pengguna gedung;

(f) penggunaan pencahayaan alami yang optimal untuk mengurangi konsumsi energi;

(g) penggunaan jenis material untuk komponen interior yang dapat mereduksi panas, tidak menimbulkan panas pada lingkungannya;

(h) sistem penghawaan dan pencahayaan buatan yang hemat energi.

Saran untuk penelitian lanjutan adalah penelitian pada lokasi dengan kondisi iklim dan lingkungan yang lebih spesifik, sehingga didapatkan gambaran yang merupakan variasi iklim dan lingkungan kampus di Indonesia. Selain itu perlu dipertimbangkan penggunaan metode penyebaran angket untuk memperluas dan memperbanyak responden, misalnya dengan memanfaatkan teknologi informasi dan komunikasi.

\section{DAFTAR PUSTAKA}

2002, Agenda 21 on Sustainable Construction, CIB \& UNEP-IETC, United Nation Environment Program / UNEP

2003, UNEP Publication on Sustainable Building and Construction, UNEP Industry and Environment, April - September 2003, United Nation Environment Program / UNEP

Evans, M. 1980, Housing, Climate and Comfort, London, The Architectural Press

GBCI, 2012, Perangkat Penilaian Greenship: GREENSHIP untuk Gedung Baru. Departmen Rating Development. Green Building Council Indonesia.

Moore, F. 1993, Environmental Control System: Heating, Cooling, Ligthing, US, McGrawHill Inc.

Priatman, Jimmy, 2003, “Energy Conscious Design" Konsepsi Dan Strategi Perancangan Bangunan Di Indonesia, Jurnal Dimensi Teknik Arsitektur Vol. 31, No. 1, Juli 2003: 43-51, Universitas Kristen Petra, Surabaya

Supranto, J.M.A. 2001. Pengukuran Tingkat Kepuasan Pelanggan untuk Menaikkan Pangsa Pasar. Jakarta: Rineka Cipta

Szokolay, S.V., 1980, Environmental Science Handbook for Architects and Builders, Lancaster, The Contruction Press

Szokolay, S.V., 1987, Thermal Design of Buildings, Canberra, RAIA Education Division

USGBC, 2008. The LEED 2009 for Existing Buildings: Operations \& Maintenance Rating System.

SNI 03-6196-2000 tentang Prosedur Audit Energi Pada Bangunan Gedung

SNI 03 6197-2000 tentang Konservasi Energi pada Sistem Pencahayaan

SNI 03-6390-2011 atau SNI edisi terbaru tentang Konservasi Energi pada Sistem Tata Udara Bangunan Gedung. 